\title{
Research of the properties of quarry tuff-stone for complex processing
}

\author{
Zinovii Malanchuk ${ }^{1, *}$, Vitalii Zaiets ${ }^{1}$, Lesia Tyhonchuk $^{1}$, Svitlana Moshchych $^{2}$, Ganbileg Gayabazar ${ }^{3}$, and Phuong Thao \\ Dang $^{4}$
}

${ }^{1}$ National University of Water Management and Environmental Management, 11 Soborna Str., Rivne, 33028, Ukraine

${ }^{2}$ Institute of Postgraduate Education, 11, 24 Serpnya Str., Rivne, 33000, Ukraine

${ }^{3}$ Mongolian University of Science and Technology, 34 Baga Toiruu, Sukhbaatar District, Ulaanbaatar, Mongolia

${ }^{4}$ Hanoi University of Mining and Geology, 18 Vien Str., Duc Thang Ward, Bac Tu Liem District, Hanoi, Vietnam

\begin{abstract}
This article focuses on the complex processing of quarry tuffs-stone to extract metals (iron, titanium, copper, silver, etc.) and obtain raw materials for construction and agriculture. The issue of tuffstone softening was investigated and the analytical dependence of the regularity of tuff-stone softening at water saturation was established, which indicates that the saturation increases with increasing mass of the sample according to the logarithmic law, and the dehydration process occurs according to the parabolic law. Also in the course of researches the magnetic susceptibility of tuff-stone was defined, which depends on size of induction of a magnetic field. The magnetically sensitive part is up to $50 \%$ by weight of the sample, and the remaining silicate part at a magnetic field strength of 1.3 Tesla. Spectral analysis showed a high content of metals in the magnetically sensitive part of tuff-stone, which consists of iron (35-40\%), titanium (2.5-4.0\%) and copper in the silicate part (0.4-0.7\%). It was found that the percentage of content representing commercial interest, and therefore it is appropriate complex processing.
\end{abstract}

\section{Introduction}

The unique basalt deposit in the Rivne region is usually accompanied by rich deposits of tuff-stone, which are the products of volcanic eruptions. Geologists' forecasts for tuff-stone raw material reserves are hundreds of millions of tons. As a mineral, they have already been widely used in agriculture to increase soil fertility and to decontaminate their radioactive contamination, as a feed additive for livestock and poultry, as well as a building material.

The growing interest in tuff-stone mining requires improving its processing and bringing to the finished product. The rich mineralogical composition of tuffs, the presence of trace elements of rare metals, high content of iron, titanium, native copper in the tuffs of Rivne-Volyn region of Ukraine necessitated their comprehensive processing, the initial stage of which is ore preparation of rock mass to extract useful components [1].

In the process of ore preparation and selection of tuffs from the dumps of the basalt quarry there is a need to study its particle size distribution for the selection of equipment for further processing. The established effect of softening of tuff-stone at repeated irrigation with water demands specification of its granulometric structure both in a dump massif, and as a result of the subsequent crushing and crushing [2-4].
The aim of the research was to establish the regularities of softening of zeolite-smectite tuffs of the quarry mining method and their magnetic susceptibility [5-9].

\section{Methods}

According to the results of previous studies, it was found [10] that the softening of quarry tuff-stone as a result of water saturation leads to its involuntary destruction, which contributes to its separation from the total dump rock mass by screening. In turn, the time of water saturation depends on the mass of the sample, so to control the process of destruction and preparation for the screening operation, it is necessary to establish such a relationship. Based on the data of the study of tuff-stone saturation with water, the saturation time was determined for samples of different masses. [11-14]. These data are presented in Table 1.

Analyzing the data shown in table 1, it was found that the saturation time increases with increasing mass. Analysis of the data suggests that the dependence can be described by logarithmic-linear regression of the form:

$$
t_{H}=a+b \cdot \ln (m),
$$

where $m$-sample weight, $t_{H}$ - saturation time.

\footnotetext{
* Corresponding author: malanchykzr@ukr.net
} 
Table 1. Saturation time for samples of different masses.

\begin{tabular}{|c|c|c|c|c|c|c|c|}
\hline Sample weight, $\mathrm{kg}$ & 0,052 & 0,106 & 0,348 & 0,681 & 1,025 & 2,18 & 3,347 \\
\hline Saturation time, $\mathrm{h}$ & 1 & 23 & 96 & 68 & 96 & 96 & 96 \\
\hline
\end{tabular}

As a result of the received data the corresponding calculations are carried out and the following model is received:

$$
t_{H}=23,34+23,2 \cdot \ln (m) .
$$

The coefficient of determination of this model is indicative of its acceptable adequacy. Graphically, the dependence was obtained (Fig. 1), which confirms that theoretically the saturation time should continue to increase with increasing mass according to the logarithmic law.

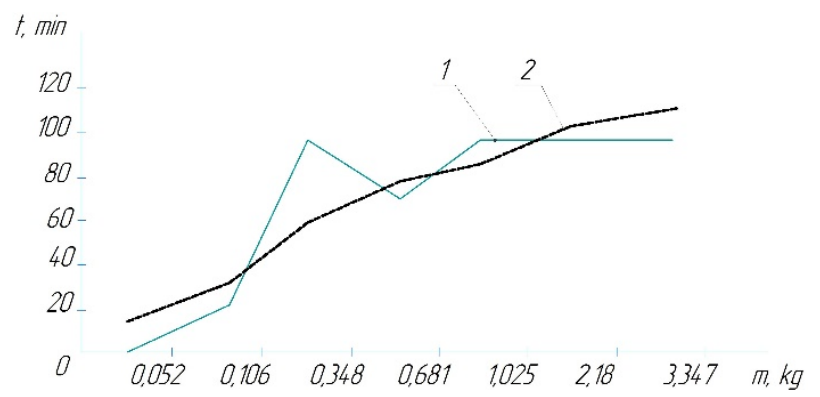

Fig. 1. The dependence of the time of saturation of tuff with water: 1 - according to the experiment; 2 - according to the calculation.

To model the process of softening of tuff-stone, it is of considerable interest to determine the analytical type of dependence on which the dehydration process takes place. Sample № 7 was taken for the study as the most characteristic for dump tuff-stone [15-17]. The analytical dependence of the species was established, and it is assumed that this dependence reduces the mass of the sample over time during dehydration.

As a result of the calculation, the following regression equation was obtained

$$
m(+)=3,54-0,00152 t \text { at } r^{2}=0,88 .
$$

The obtained model has a fairly high level of adequacy, but the consistency of experimental and theoretical values $m(t) n$ graphical form is not satisfactory (Fig. 2).

In this regard, a parabolic regression model of the species was calculated $m(t)=a+b t+c t^{2}$. This model, unlike the previous one, takes into account the nonlinear nature of the process. The result is obtained

$$
m(t)=3,569-0,00327 t+0,0000124 t^{2} \text { at } r^{2}=0,98,
$$

which is significantly higher than for the linear model.

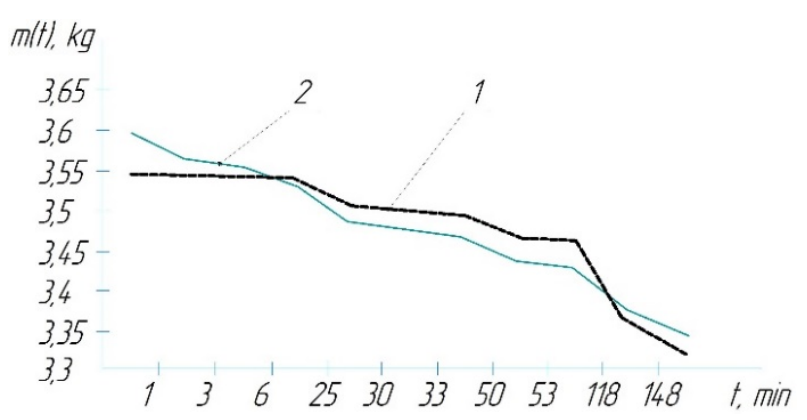

Fig. 2. Linear model of tuff-stone dehydration process: 1 experimental; 2 - estimated.

The graph of actual and analytical parabolic dependences is given in Fig. 3, which shows their consistency. Thus, it can be argued that the process of dehydration is subject to the parabolic model, which is shown in Fig. 3.

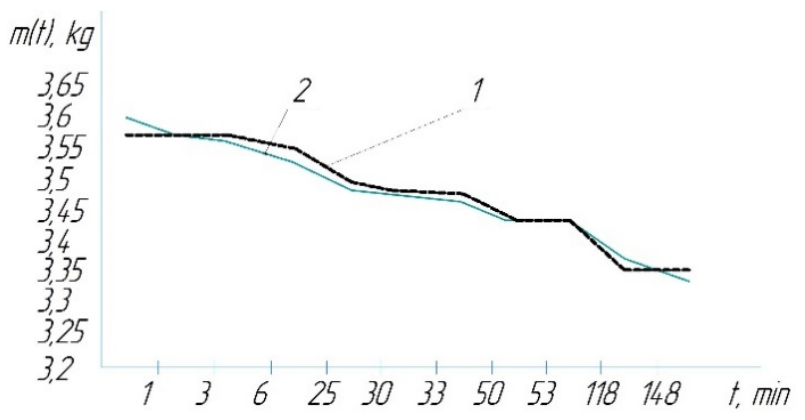

Fig. 3. Parabolic model of the process of dehydration of tuffstone: 1 - experimental; 2 - calculated.

As a rule, in practice one cycle of saturation and dehydration is not enough for destruction of tuff-stone in a dump to the conditional sizes. Therefore, it is recommended to use a repeated cycle of saturation and subsequent dehydration naturally - drying [18-23].

Analysis of data on the re-saturation of tuff-stone with water and testing on these data of different regression models allowed to choose the most adequate of them:

$$
m(t)=a+b_{1} t+b_{2} m_{0}+b_{3} m_{0} t,
$$

where $m_{0}$ - the initial mass of the sample, before saturation; $t$ - saturation time.

As a result of the calculations, the following model was obtained

$$
m(t)=0,0075-0,00004 t+1,0285 m_{0}+0,00016 m_{0} t .
$$


Coefficient of determination $r^{2}=0,99$ and indicates an acceptable functional dependence $m(t)$. Given the rather large sample size $(n=56)$, this model can be adopted for further practical use. It takes into account not only the influence of time and mass of the sample separately, but also the combined influence of these factors. To illustrate the results in Fig. 4 shows the dependences of the mass of tuff-stone on time for three samples: $m_{01}=1,025 \mathrm{~kg}$; $m_{02}=2,18 \mathrm{~kg}$ and $m_{03}=3,347 \mathrm{~kg}$.

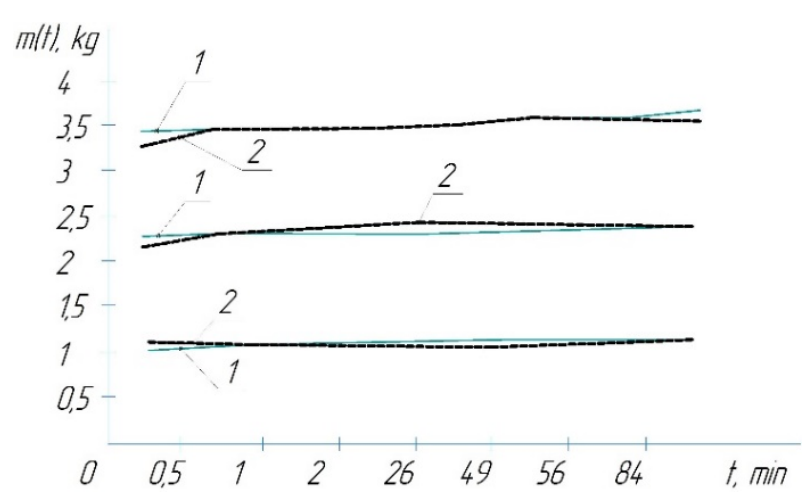

Fig. 4. The dependence of the mass of the tuff-stone sample on the re-saturation of three samples with water: 1 -according to the experiment; 2 - by calculation.

According to experimental studies, a regression model was obtained for the process of re-dehydration

$m(t)=0,00137-0,000045 t+1,0697 m_{0}-0,000063 m_{0} t$.

Coefficient of determination is $r^{2}=0,99$.

Model $m_{0}$ - the mass of the sample after dehydration.

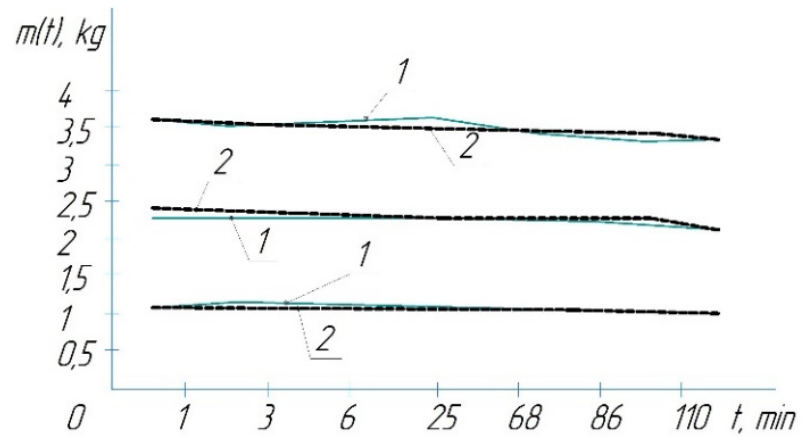

Fig. 5. The dependence of the mass of the tuff-stone sample during repeated dehydration for three samples: 1 -according to the experiment; 2 - by calculation.

In Fig. 5 shows the experimental data and the results of analytical calculations according to the above model. The high level of coincidence of graphs indicates the reliability of the chosen model and the possibility of its application in practice.

Thus, as a result of research the analytical dependence of the regularity of softening at water saturation was established, which shows that the saturation increases with increasing mass of the sample according to the logarithmic law, and the dehydration process occurs according to the parabolic law. tuff processing.

\section{Investigation of the magnetic susceptibility of zeolite-smectite tuff- stone}

In recent years, researchers' interest in tuffs in order to use them in industry has grown significantly. Therefore, there is a need for a detailed study of their properties, methods of extraction, processing and integrated use. In the process of research of zeolite-smectite tuffs, which occur in large quantities in Rivne-Volyn, their magnetic susceptibility was established, which is explained by the presence of iron and titanium. Quantitative and qualitative analysis of the content of these elements was performed experimentally using magnetic and spectral analyzes of crushed tuff-stone samples of different sizes at variable magnetic field strength to determine the level of its sufficiency in the ore preparation of raw materials for complex processing [24-27].

Studies have shown that tuff-stone contains native copper in the form of thin films or point inclusions, the extraction of which is possible only with fine grinding of tuff-stone for maximum separation of the silicate part from native inclusions. Since iron and titanium are also in the joints in the form of compounds, by fine grinding followed by screening to achieve maximum disclosure of minerals. Obtaining the maximum allowable degree of grinding of tuff-stone for reasons of the possibility of a hardware method of extracting metal compounds (magnetic and electric separators) allows to determine the content of silicate and metal parts in the composition of tuff-stone [28-30].

The purpose of studies of the composition of tuffstone by magnetic and spectral analysis was to determine the particles of silicate and metal parts, as well as the influence of magnetic field strength on the extraction of the magnetically sensitive part and its composition.

Because zeolite-smectite tuffs are associated rocks in basalt mining and are not widely used, they are a waste rock in basalt quarries. From the point of view of complex extraction and processing of basalts with division into three components in the deposit (basalt, lavobrekcia and tuff), the Rafalivka deposit is perspective, therefore researches of zeolite-smectite tuff-stone of this deposit are executed in work. In the process of ore preparation for this method of tuff-stone processing it is important for rationalization to determine the basic particle size and chemical composition and reaction of rock mass to different types of influences [31-32].

For research, the tuff of the Rafalivka basalt quarry was crushed into three groups of size: $(-2.5+0.63 \mathrm{~mm})$; $(-0.63+0.1 \mathrm{~mm})$; and $(-0.1 \mathrm{~mm})$. Next, the weight fraction of each size class in the sample and the percentage of magnetically sensitive part in it was determined (Table 2). The magnitude of the magnetic field for each sample varied stepwise from 0.08 Tesla to 1.3 Tesla in five stages of exposure. The experimental technique involved increasing the induction of the magnetic field to determine the part of the tuff-stone separated from the total mass of 
the part that was attracted at a given intensity, and then, by spectral analysis, the content of the elements of each part was determined. This is due to the fact that the degree of susceptibility of tuff increases with increasing magnetic field strength. Factors influencing the process of magnetic separation are particle size distribution and chemical composition of tuff-stone [33].

Table 2. The distribution of the mass of tuff-stone in the sample depending on the induction.

\begin{tabular}{|c|c|c|c|c|c|c|c|}
\hline \multirow{2}{*}{$\begin{array}{l}\text { № } \\
\text { research }\end{array}$} & \multicolumn{3}{|c|}{ Class $+0,63-2,5$} & \multirow[b]{2}{*}{$\begin{array}{l}\text { № } \\
\text { research }\end{array}$} & \multicolumn{3}{|c|}{ Class $+0,1-0,63$} \\
\hline & \begin{tabular}{|l|}
$\begin{array}{l}\text { Induction, } \\
\text { Tesla }\end{array}$ \\
\end{tabular} & $\begin{array}{l}\text { Susceptible mass, } \\
m, \mathrm{~g}\end{array}$ & $\begin{array}{l}\text { Percentage, } \\
\gamma, \%\end{array}$ & & $\begin{array}{l}\text { Induction, B, } \\
\text { Tesla }\end{array}$ & $\begin{array}{l}\text { Susceptible mass, } \\
m, \mathrm{~g}\end{array}$ & $\begin{array}{l}\text { Percentage, } \\
\gamma, \%\end{array}$ \\
\hline 1 & 0,08 & 63,2 & 19,1 & 8 & 0,08 & 30,5 & 14,6 \\
\hline 2 & 0,16 & 59,5 & 18,0 & 9 & 0,16 & 37,0 & 17,7 \\
\hline 3 & 0,3 & 51,7 & 15,6 & 10 & 0,3 & 37,7 & 18,1 \\
\hline 4 & 0,44 & 49,7 & 15,0 & 11 & 0,44 & 31,9 & 15,3 \\
\hline 5 & 0,58 & 44,8 & 13,5 & 12 & 0,58 & 32,5 & 15,6 \\
\hline 6 & 1,3 & 6,1 & 1,8 & 13 & 1,3 & 5,8 & 2,8 \\
\hline 7 & nonmagnetic & 56,4 & 17,0 & 14 & nonmagnetic & 33,4 & 15,9 \\
\hline & Total (sum) & 331,4 & 100 & & Total (sum) & 208,9 & 100 \\
\hline
\end{tabular}

Since the third group of size (-100 microns) showed complete magnetic immunity, it is attributed to the nonmagnetic part of the sample.

Based on the obtained results, the magnetically impermeable part of the sample is $49.1 \%$ or $194.3 \mathrm{~g}$. The different susceptibility of the metallized part of the crushed tuff-stone in relation to the magnitude of the magnetic field induction and size indicates product.

The nature of the heterogeneity of the composition was established by spectral analysis of all obtained fission products. The analysis was performed by spilling on the device STE-1 with a prefix USI-10. The results of the analysis are presented in Table 3 and Table 4 . It should be noted the lack of accuracy in the percentage of some elements, in particular titanium $(>1.0 \%)$, iron $(>15 \%)$, and the lack of data on the presence of silicates and carbonates $\left(\mathrm{SiO}_{2}\right.$ and $\left.\mathrm{CaO}\right)$ in samples. Their content was determined by chemical analysis. It was precisely established that the iron content in the samples of the first group is $36.2 \%$, and in the second $-39.6 \%$, respectively, titanium $-1.3 \%$ and $4.1 \%$. The increase in the average percentage of native copper in the sample of the second group of size is explained by the fineness of its inclusions, but this indicator requires additional separate studies [3437].

Table 3. The results of the analysis of the content of elements in the tuff-stone for the sample 1.

\begin{tabular}{|c|c|c|c|c|c|c|c|c|c|c|c|}
\hline \multirow{2}{*}{ № } & \multirow{2}{*}{$\begin{array}{l}\text { Induction, } \\
\text { Tesla }\end{array}$} & \multirow{2}{*}{$\begin{array}{l}\text { The weight of the sample in the } \\
\text { first group, } g\end{array}$} & \multirow{2}{*}{$\begin{array}{l}\text { The mass content in the } \\
\text { sample, } \%\end{array}$} & \multicolumn{8}{|c|}{ Content of elements, \% } \\
\hline & & & & $\mathbf{F e}$ & $\mathbf{T i}$ & $\mathbf{C u}$ & Mn & $\mathbf{B a}$ & $\mathrm{SiO}_{2}$ & $\mathrm{CaO}$ & Ag, g/t \\
\hline 1 & 0,08 & 63,2 & 19,1 & $>15$ & $>1,0$ & 0,1 & 0,07 & 0,07 & 43,8 & 3,44 & 15 \\
\hline 2 & 0,16 & 59,5 & 18,0 & $>15$ & $>1,0$ & 0,4 & 0,07 & 0,05 & 43,8 & 3,44 & 10 \\
\hline 3 & 0,3 & 51,7 & 15,6 & $>15$ & $>1,0$ & 0,2 & 0,05 & 0,07 & 43,8 & 3,44 & 7 \\
\hline 4 & 0,44 & 49,7 & 15,0 & $>15$ & $>1,0$ & 0,3 & 0,07 & 0,05 & 43,1 & 3,04 & 10 \\
\hline 5 & 0,58 & 44,8 & 13,5 & $>15$ & $>1,0$ & 0,5 & 0,07 & 0,07 & 43,1 & 3,04 & 10 \\
\hline 6 & 1,3 & 6,1 & 1,8 & $>15$ & 0,7 & 0,5 & 0,05 & 0,07 & 43,1 & 3,04 & 15 \\
\hline 7 & nonmagnetic & 56,4 & 17,0 & $>15$ & & 0,4 & 0,05 & 0,065 & 43,8 & 51,6 & 50 \\
\hline$\Sigma$ & & 331,4 & 100 & $>15$ & $>1,0$ & 0,45 & 0,06 & 0,06 & 43,5 & 52,0 & 17 \\
\hline
\end{tabular}

Table 4. The results of the analysis of the content of elements in the tuff-stone for the sample 2.

\begin{tabular}{|c|c|c|c|c|c|c|c|c|c|c|c|}
\hline \multirow[b]{2}{*}{ № } & \multirow[b]{2}{*}{$\begin{array}{l}\text { Induction, } \\
\text { Tesla }\end{array}$} & \multirow[b]{2}{*}{$\begin{array}{l}\text { The weight of the sample in the } \\
\text { first group, } g\end{array}$} & \multirow[b]{2}{*}{$\begin{array}{l}\text { The mass content in the } \\
\text { sample, } \%\end{array}$} & \multicolumn{8}{|c|}{ Content of elements, $\%$} \\
\hline & & & & $\mathbf{F e}$ & $\mathbf{T i}$ & $\mathrm{Cu}$ & Mn & Ba & $\mathrm{SiO}_{2}$ & $\mathrm{CaO}$ & $\begin{array}{l}\mathbf{A g}, \\
\mathrm{g} / \mathrm{t}\end{array}$ \\
\hline 8 & 0,08 & 30,5 & 14,6 & $>15$ & $>1,0$ & 0,1 & 0,07 & 0,07 & 42,1 & 51,8 & 7 \\
\hline 9 & 0,16 & 37,0 & 17,7 & $>15$ & $>1,0$ & 0,4 & 0,07 & 0,06 & 43,1 & 51,9 & 10 \\
\hline 10 & 0,3 & 37,7 & 18,1 & $>15$ & $>1,0$ & $.0,5$ & 0,05 & 0,07 & 43,1 & 52,3 & 10. \\
\hline 11 & 0,44 & 31,9 & 15,3 & $>15$ & $>1,0$ & 0,7 & 0,07 & 0,07 & 42,8 & 51,2 & 15 \\
\hline 12 & 0,58 & 32,5 & 15,6 & $>15$ & $>1,0$ & 0,5 & 0,07 & 0,07 & 41,7 & 52,1 & 15 \\
\hline 13 & 1,3 & 5,8 & 2,8 & 1,0 & 0,5 & 0,5 & 0,15 & 0,05 & 44,6 & 53,2 & 50 \\
\hline 14 & nonmagnetic & 33,4 & 15,9 & & & 0,6 & 0,1 & 0,04 & 43,5 & 53,1 & 50 \\
\hline$\Sigma$ & & 208,9 & 100 & & & 0,5 & 0,08 & 0,05 & 43,6 & 52,6 & 23 \\
\hline
\end{tabular}

As the experiment showed, the discrepancy in the mass of the magnetically sensitive part (49\%), which is due to the presence of titan magnetite and iron content in the samples obtained by chemical analysis (36.2-39.6\%), is due to the presence of splices with hollow rock. The presence of copper in the magnetically sensitive part indicates the need to choose a rational degree of grinding of tuff-stone for a more complete separation of copper 
from the silicate part. At the same time the particles of titan magnetite are more fully revealed. Since magnetic separation allows to separate even finely divided iron particles (up to 44 microns) from crushed tuff-stone to a size of less than 100 microns, the electric separation of the silicate part of the product in copper extraction is most effective up to a size of 100 microns. This indicates that the re-grinding of tuffs in the ore preparation process leads to losses in the extraction of metals [38-40].

Thus, the performed researches established that the degree of grinding of tuff-stone in the process of ore preparation should be not less than $0.05-0.1 \mathrm{~mm}$. The magnetically sensitive part reaches $49 \%$ by weight of the sample, respectively; the silicate part is $50-51 \%$. During the extraction of the magnetically sensitive part is significantly affected by the magnetic field strength, which reaches 1.3 Tesla. The performed studies indicate the expediency of complex processing of not only basalts but also tuffs, as the percentage of basic elements is of industrial interest. Such elements are iron, titanium, copper, silver. The remaining silicate part is disposed of for construction and agriculture. This recycling technology is waste-free and resource-saving.

\section{Conclusions}

Analysis of experimental studies suggests that tuff-stone is a valuable raw material of interest to industry, as it contains valuable elements in the form of native copper, iron, titanium. Removal of these components is technologically possible and economically feasible.

For dump tuff-stone, an analytical dependence of the regularity of softening at water saturation is established, which indicates that the saturation increases with increasing mass of the sample according to the logarithmic law, and the dehydration process occurs according to the parabolic law.

As a result of the conducted researches the magnetic susceptibility of tuff-stone which depends on size of induction of a magnetic field was established. The magnetically sensitive part of tuff-stone, at a magnetic field strength of 1.3 , Tesla is up to $50 \%$ by weight of the sample, and the rest is the silicate part. The spectral analysis showed a high content of metals in the magnetically sensitive part of tuff-stone, which consists of iron (35-40\%), titanium $(2.5-4.0 \%)$ and copper in the silicate part $(0.4-0.7 \%)$. The percentage of these elements is of industrial interest, so it is advisable to comprehensively process dump tuffs in the Rivne-Volyn region of Ukraine.

\section{References}

1. J. Zeng, J. Li, H. Zhu, Geologic Feature of Shilipo Copper Deposit in Xinjiang. Advanced Materials Research 881-883, 1607-1610 (2014). doi:10.4028/www.scientific.net/AMR.881-883.1607

2. S.-B. Choi, Y.-H. Kim, A New Processing Technology of Comprehensive Utilization on the Gold Copper Ore. Advanced Materials Research
1089 , $53-58$ (2015). doi:10.4028/www.scientific.net/AMR.1089.53

3. J. Wu, J. Yang, N. Nakagoshi, X. Lu, H. Xu, Process Mineralogy of a Low Grade Cu-Ni-PGM Sulphide Ore and its Implications for Mineral Processing. Advanced Materials Research 524-527, 1023-1028 (2012). doi:10.4028/www.scientific.net/AMR.524527.1023

4. J. (C.M.) Kao, W.-P. Sung, R. Chen, Flotation of Copper Oxide Minerals Using Ethylene Phosphate as Activators. Advanced Materials Research 581-582, 975-982 doi:10.4028/www.scientific.net/AMR.581-582.975

5. J. Li, H. Hu, Development and Utilization of Circular Economy and Urban Mining - Chengdu City Based Renewable Resource Industry Survey. Applied Mechanics and Materials 768, 644-651 (2015). doi:10.4028/www.scientific.net/AMM.768.644

6. A. Baibatsha, K. Dyussembayeva, A. Bekbotayev, Material Composition of Technogenic Ores in Tails of Zhezkazgan Enrichment Factory (Central Kazakhstan). Applied Mechanics and Materials 858, 366-370 (2016). doi:10.4028/www.scientific.net/AMM.858.366

7. X.D. Xu, B. Li, Q.M. Lu, X.Y. Yan, J.L. Li, Flotation Test of High Sulfur Copper Ore in the Northwest in Yunnan. Applied Mechanics and Materials (556-562, 201-204 doi:10.4028/www.scientific.net/AMM.556-562.201

8. G. Chang, J.-Sh. Young, W. Wisnoe, Novel Method of Developing Nanosilica Coated Alumina Micro Abrasives Using Silicon Nanoparticles Generated from Spark Erosion as the Source. Applied Mechanics and Materials 799-800, 479-482 (2015). doi:10.4028/www.scientific.net/AMM.799-800.479

9. O.V. Samoilova, E. A. Trofimov, E.R. Vakhitova, Effect of Cerium and Lanthanum Additives on the Phase Composition of the Copper-Nickel Alloys. Materials Science Forum 946, 123-128 (2019). doi:10.4028/www.scientific.net/MSF.946.123

10. Y. Q. Meng, Sh. J. Dai, Zh. G. Hu, L. N. Tian, The Experiment Study on a Copper-Molybdenum Ores in Mongolia. Advanced Materials Research 454, 342347 doi:10.4028/www.scientific.net/AMR.454.342

11. Y. V. Chui, On conjugation conditions in the filtration problems upon existence of semipermeable inclusions. JP Journal of Heat and Mass Transfer 15(3), 609-619 (2018). doi: $10.17654 / \mathrm{hm} 015030609.9$

12. K. Rysbekov, D. Huayang, T. Kalybekov, M. Sandybekov, K. Idrissov, Y. Zhakypbek, G. Bakhmagambetova, Application features of the surface laser scanning technology when solving the main tasks of surveying support for reclamation. Mining of Mineral Deposits 13(3), 40-48 (2019). doi:10.33271/mining13.03.040

13. I. D. Van der Werf, D. Fico, G. E. De Benedetto, L. Sabbatini, The molecular composition of Sicilian 
amber. Microchemical Journal 125, 85-96 (2016). http://doi.org/10.1016/j.microc.2015.11.012

14. V.I. Alekseev, The beetles (Insecta: Coleoptera) of Baltic amber: the checklist of described species and preliminary analysis of biodiversity. Zoology and Ecology 23(1), 5-12 doi:10.1080/21658005.2013.769717

(2013).

15. B.R. Rakishev, A.A. Orynbay, A.M. Auezova, A.E. Kuttybaev, Grain size composition of broken rocks under different conditions of blasting. Mining Informational and Analytical Bulletin (8), 83-94 (2019). doi:10.25018/0236-1493-2019-08-0-83-94

16. O. Kovrov, K. Babiy, B. Rakishev, A. Kuttybayev, Influence of watering filled-up rock massif on geomechanical stability of the cyclic and progressive technology line. Mining of Mineral Deposits 10(2), 55-63 (2016). doi:10.15407/mining10.02.055

17. D. Antoljak, D. Kuhinek, T. Korman, T. Kujundzic, Dependency of specific energy of rock cutting on specific drilling energy. Rudarsko Geolosko Naftni Zbornik 33(3), 23-32 doi:10.17794/rgn.2018.3.3

18. A. Kopesbayeva, A. Auezova, M. Adambaev, A. Kuttybayev, Research and development of software and hardware modules for testing technologies of rock mass blasting preparation, in New Developments in Mining Engineering 2015: Theoretical and Practical Solutions of Mineral Resources Mining (CRC Press, 2015), pp. 185-192. doi:10.1201/b19901-34

19. B.R. Rakishev, A.M. Auezova, A.Ye. Kuttybayev, A.U. Kozhantov, Specifications of the rock massifs by the block sizes. Naukovyi Visnyk Natsionalnoho Hirnychoho Universytetu. 6, 22-27 (2014)

20. O. Belichenko, J. Ladzhun, Complex gemological research of new types of treated amber. Visnyk of Taras Shevchenko National University of Kyiv. Geology 4(75), 30-34 (2016). doi:10.17721/17282713.75.04

21. A. Krek, M. Ulyanova, S. Koschavets, Influence of land-based Kaliningrad (Primorsky) amber mining on coastal zone. Marine Pollution Bulletin (131), 1-9 (2018). doi:10.1016/j.marpolbul.2018.03.042

22. J. Poulin, K. Helwig, The characterization of amber from deposit sites in western and northern Canada. Journal of Archaeological Science: Reports (7), 155168 (2016). doi:10.1016/j.jasrep.2016.03.037

23. A. Kostina, V. Zvereva, A. Pyatakov, Influence of Sulfur Content in Tailings on Processes of Hypergene and Technogene Mineral Formation on the Example of Kavalerovo Tin-Ore District. Advanced Materials Research 1051, 605-609 (2014). doi:10.4028/www.scientific.net/AMR.1051.605

24. A. Kozhonov, Zh. Maymanova, A. V. Kritskii, Choice of Efficient Technology for Aged Enrichment Tailings Processing. Materials Science Forum 946, 558-563 doi:10.4028/www.scientific.net/MSF.946.558
25. Abhilash, B.D. Pandey, T.R. Mankhand, Copper Refining Electrolyte and Slime Processing Emerging Techniques. Advanced Materials Research 828, 93-115 (2013). doi:10.4028/www.scientific.net/AMR.828.93

26. A. D. Tommaso, C. Gentilini, G. Castellazzi, Effect of the Presence of Mortar Joints in the Bond Behaviour of Tuff Masonry Elements. Key Engineering Materials 624, 526-533 (2014). doi:10.4028/www.scientific.net/KEM.624.526

27. Z. Liu, X. Dong, Zh. Liu, Q. Liu, The Study on Copper-Molybdenum Polymetallic Mine OreControlling Structure Conditions and Mineralization Forecast of the Jiudingshan. Advanced Materials Research 807-809, 2205-2208 (2013). doi:10.4028/www.scientific.net/AMR.807-809.2205

28. S. Semerikov, S. Chukharev, S. Sakhno, A. Striuk, V. Osadchyi, V. Solovieva, T. Vakaliuk, P. Nechypurenko, O. Bondarenko, H. Danylchuk, Our sustainable coronavirus future. $\mathrm{E} 3 \mathrm{~S}$ Web of Conferences 166, $00001 \quad$ (2020). doi:10.1051/e3sconf/202016600001

29. M. Dondi, P. Cappelletti, G. Cerri, M. Gennaro, R. Gennaro, A. Langella, Zeolitic Tuffs as Raw Materials for Lightweight Aggregates. Key Engineering Materials 264-268, 1431-1434 (2004). doi:10.4028/www.scientific.net/KEM.264-268.1431

30. S. Sakhno, L. Yanova, O. Pischikova, S. Chukharev, Study of the influence of properties of dusty ferromagnetic additives on the increase of cement activity. E3S Web of Conferences 166, 06002 (2020). doi:10.1051/e3sconf/202016606002

31. V. J. Zepeda, D. Cautivo, P. A. Galleguillos, J. Soto, Y. Contador, C. Demergasso, Bioleaching of Covellite from Low Grade Copper Sulphide Ore and Tails. Advanced Materials Research 825, 262-265 (2013). doi:10.4028/www.scientific.net/AMR.825.262

32. Q. Y. Xing et al., Study on the Gemological Characteristics of Amber from Myanmar and Chinese Fushun, Key Engineering Materials 544 (2013). doi:10.4028/www.scientific.net/KEM.544.172

33. Y. Malanchuk, Z. Malanchuk, V. Korniienko, S. Gromachenko, The Results of Magnetic Separation Use in Ore Processing of Metalliferous Raw Basalt of Volyn Region. Mining of Mineral Deposits 10(3), 7783 (2016). doi:10.15407/mining10.03.077

34. A.M. Zakharenko, K.S. Golokhvast, Using Confocal Laser Scanning Microscopy to Study Fossil Inclusion in Baltic Amber, a New Approach. Key Engineering Materials 806 (2019). doi:10.4028/www.scientific.net/KEM.806.192

35. V. Panayotov, M. Panayotova, S. Chukharev S. Recent studies on germanium-nanomaterials for LIBs anodes. E3S Web of Conferences 166, 06012 (2020). doi:10.1051/e3sconf/202016606012

36. S. Pysmennyi, M. Fedko, N. Shvaher, S. Chukharev, Mining of rich iron ore deposits of complex structure 
under the conditions of rock pressure development. E3S Web of Conferences 201, 01022 (2020). doi:10.1051/e3sconf/202020101022

37. V. Nadutyi, V. Korniyenko, Z. Malanchuk, O. Cholyshkina, Analytical presentation of the separation of dense suspensions for the extraction of amber. E3S Web of Conferences 109, 00059 (2019). doi:10.1051/e3sconf/20191090005

38. V. Moshynskyi, Z. Malanchuk, V. Tsymbaliuk, L. Malanchuk, R. Zhomyruk, O. Vasylchuk, Research into the process of storage and recycling technogenic phosphogypsum placers. Mining of Mineral Deposits 14(2), 95-102 (2020). doi:10.33271/mining14.02.095

39. V. Korniyenko, V. Nadutyi, Y. Malanchuk, M. Yeluzakh, Substantiating velocity of amber buoying to the surface of sludge-like rock mass. Mining of Mineral Deposits 14(4), 90-96 (2020). doi:10.33271/mining 14.04.090

40. Ye. Malanchuk, V. Korniienko, L. Malanchuk, V. Zaiets, Research into the moisture influence on the physical-chemical tuff-stone characteristics in basalt quarries of the Rivne-Volyn region. E3S Web of Conferences, 211, $01036 \quad$ (2020). doi:10.1051/e3sconf/202020101036 